\title{
Editorials
}

\section{CHANGE IN EDITORSHIP OF LEPROSY REVIEW}

With the publication of this issue Dr Frank Davey retires as Editor of Leprosy Review. He was invited to undertake this responsibility after a lifetime of service as a leprologist, for many years in Nigeria and more recently in India, with particular experience in leprosy control, and clinical aspects of leprosy research. In Nigeria he became Senior Specialist and Adviser to the Federal Government. In an interlude in London as Medical Adviser to the Methodist Missionary Society, he was able to respond to Dr Robert Cochrane's invitation to become Joint Editor with him of the Second Edition of Leprosy in Theory and Practice.

During his five years as Editor, Leprosy Review has prospered and its circulation has reached record figures. An emphasis on the field worker and the speedy publication of original articles have been features of these years. Above all else by his enthusiasm and dedication Dr Davey sustained Leprosy Review as a leading Journal for the most rapid publication of practical and basic aspects of leprosy.

At his last Editorial Board as Chairman, Dr Davey paid tribute to the distinguished service members of the Board and other consultants had rendered as specialist referees, especially to Dr R. J. W. Rees, Vice-Chairman, for his encouragement and advice, and to Mr G. F. Harris, Director of LEPRA, for the constant support of Leprosy Review which had made possible an increase in size of the Journal and facilitated both wider circulation and Special Issues.

In recognition of Dr Davey's services, the Executive Committee of LEPRA have invited him to become Editor Emeritus.

Dr Davey is succeeded as Editor and Chairman of the Board by Dr Colin McDougall, LEPRA'S Medical Consultant, who combines particular experience of clinical leprosy and leprosy control in Africa, with most distinguished service in the sphere of histopathology. His laboratory at Oxford is well known.

The preparation of material for Vol. 50 No. 1 is already far advanced. From now on, the address of the Editorial Office is: Dr A. C. McDougall, The Slade Hospital, Headington, Oxf ord $\mathrm{OX} 3 \mathrm{7JH}$

R. J. W. REES

(Vice-Chairman, Editorial Board) 